http://kitaibelia.unideb.hu/

ISSN 2064-4507 (Online) • ISSN 1219-9672 (Print)

(C) 2015, Department of Botany, University of Debrecen, Hungary

20 (1): 44-47.; 2015

DOI: $10.17542 /$ kit.20.44

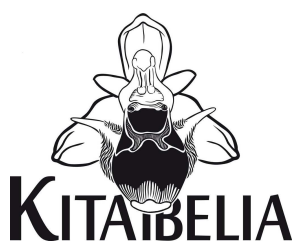

\title{
A Ceratochloa (DC. et P. Beauv.) Hack. alnemzetség (Bromus L., Poaceae) hazai története és elterjedése
}

\author{
KovÁCS Dániel ${ }^{*}$ \& MESTERHÁZY Attila²
}

(1) Pécsi Tudományegyetem, Ökológiai Tanszék, H-7624 Pécs, Ifjúság útja 6.; *dancs12@msn.com (2) H-9500 Celldömölk, Hunyadi utca 55.; amesterhazy@gmail.com

\section{The subgenus Ceratochloa (DC. et P. Beauv.) Hack. (Bromus L., Poaceae) in Hungary}

\begin{abstract}
The subgenus Ceratochloa is a taxonomically difficult small group of the genus Bromus. The species of this subgenus are mostly native to America, and are often introduced to other continents. Two species of them, namely B. catharticus and B. carinatus have been reported from Hungary so far. Bromus catharticus was first found in Győr city in the 1910s, much later (in the 2000s) in Környe and Kálmánháza villages. The Hungarian records of $B$. carinatus come from Keszthely and Sopron cities. We have recently found two new occurrences of B. catharticus in the city of Pécs, South Hungary.
\end{abstract}

Keywords: alien flora, Bromus carinatus, Bromus catharticus

Összefoglalás - A Ceratochloa alnemzetség a Bromus nemzetség egyik kicsi, de igen bonyolult taxonómiájú csoportja. Az ide tartozó fajok főként Észak- és Dél-Amerikában őshonosak, de adventívként a többi földrészen is jelen vannak. Hazánkból eddig két fajt mutattak ki, a Bromus catharticus-t és a B. carinatus-t. Az előbbit először Győrből, majd Környéről és a Nyírség nyugati feléről (Kálmánháza) jelezték. Utóbbi fajnak pedig Keszthely és Sopron területéről ismertek adatai. Az elmúlt években végzett intenzív városi flórakutatás során a $B$. catharticus két új populációja került elő Pécs városából.

Kulcsszavak: adventív flóra, Bromus carinatus, Bromus catharticus

\section{Bevezetés}

A Bromus L. a Poaceae családba tartozó, 100-400 fajt magában foglaló nemzetség (VERLOovE 2012). Hét alnemzetségre osztják, ezek egyike a Ceratochloa (DC. et P. Beauv.) Hack., mely 10-16 fajt tartalmaz. Taxonómiailag ez a legbonyolultabb csoport (WILLIAMS et al. 2011). A fajok többsége az amerikai kontinens különböző részein őshonos, de vannak afrikai eredetúek is (például B. leptoclados Nees). Egyes fajok (például B. stamineus É. Desv., B. catharticus Vahl) mezőgazdasági hasznára már korán felfigyeltek, és számos országban (például Ausztrália, Franciaország, Új-Zéland, USA) termesztésbe vonták őket (STEWART 1996, WiLliams et al. 2011). Egyrészt a termesztésük okán, másrészt spontán terjedés révén Európa legtöbb országában jelen van a B. catharticus és a B. carinatus fajcsoport.

A Bromus-ok hazai kutatásának történetét SoMLYAY (2001) foglalja össze igen alaposan. Azonban a Ceratochloa alnemzetséget csak röviden tárgyalja. Egyrészt azt aktuális adatok hiányában kipusztultnak (B. catharticus), másrészt az újonnan kimutatott B. carinatus Hook. et Arn.-nal együtt az eddig megtalált két fajt „feltehetően átmenetileg megtelepedő”-nek tartja. 


\section{Hazai elterjedés}

Magyarország területéről a tárgyalt alnemzetség két faját mutatták ki eddig. Az egyik a $B$. catharticus [syn.: B. unioloides (Willd.) Humb. et Kunth, B. willdenowii Kunth], melyet először Polgár Sándor talált 1910-ben Győrött (PolGÁR 1912) (BP 14781), majd két évtizeden át a város több pontjáról is jelezte (Polgár 1914, 1918, TAKÁcS et al. 2014) (BP 270543, BP 14782, BP 14783, DE-soo-05257, DE-soo-05258). A faj eltűnésére már maga Polgár is felfigyelt (POLGÁR 1941), legutolsó gyűjtése 1928-ból származik (BP 270544). Győrben azóta sem került elő újra, így innen kipusztultnak tekinthető (SCHMIDT 2014). A taxon hazai történetében ez után egy több évtizedes szünet következik. 1950-ből azonban van egy igen bizonytalan lokalitású adata „Neszmély?” helymegjelöléssel (PÉNZES, BP 402349), maga a példány is érdekes, mivel csupán két füzérkéből áll. Később Környén találta meg BARINA (2007), legutóbb pedig a Nyírségből, Kálmánháza mellől jelezték (KIRÁLY et al. 2010).

A hazánkból előkerült másik faj a B. carinatus. Első gyűjtése 1965-ből származik Keszthelyről. A példányt eredetileg B. catharticus -nak vélték (ALMÁDY, BP 284087), azonban egyértelműen az előbbi fajjal azonosítható (Revid.: KovÁcs D., 2014.12.12). A tévedésre KIRÁLY \& KIRÁLY (1999) nyomán már ALMÁDI (2002) is rámutatott, aki arról számolt be, hogy a fajjal 1972-ig sikeres termesztési kísérleteket folytattak, majd a kutatás hirtelen félbeszakadt. A fajt azonban nem sikerült maradéktalanul kiirtani, Almádi László még a 2000-es évek elején is gyűjtötte az egyetemi szőlősben (BP 652905, BP 652906; JPU s. n.). 1997-ben Sopronból, a Győri úton, járdaszegélyből került elő egy kisebb populáció (KIRÁLY \& KIRÁLY 1999) (BP 291755).

Pécs város flórájának kutatása során a $B$. catharticus két újabb populációját fedeztük fel. A bizonyító példányok a Pécsi Tudományegyetem Herbáriumában (JPU) kerültek elhelyezésre.

A Bromus catharticus új lelőhelyei a Dél-Dunántúlon:

Pécs, a Bányakapitányság udvarán 20-25 m²-es területen szórványosan (2010.06.29., Leg./Det:: Mesterházy A.) [9975.1]. Kísérő fajok: Amaranthus deflexus, Ballota nigra, Bellis perennis, Cynodon dactylon, Festuca pratensis, Geranium pusillum, Glechoma hederacea, Hedera helix, Leontodon autumnalis, Lolium perenne, Medicago lupulina, Oxalis corniculata, Plantago lanceolata, Poa pratensis agg., Polygonum aviculare agg., Potentilla reptans, Prunella vulgaris, Sonchus oleraceus, Taraxacum officinale, Veronica persica, Viola spp.

Pécs, Magyarürög, a Sirály utca és a Templom köz sarkán $6 \times 0,5$ m-es állomány (2014.10.18., Leg./Det.: Kovács D.) [9975.1]. Kísérő fajok: Ballota nigra, Bromus sp., Cichorium intybus, Crepis rhoedifolia, Erigeron annuus, Geum urbanum, Hedera helix, Medicago arabica, Poa annua, Polygonum aviculare agg., Silene alba, Sonchus oleraceus, Taraxacum officinale, Viola arvensis.

Mindkét Bromus faj szerepel BALOGH et al. (2004) listáján, mint alkalmi neofiton. A $B$. carinatus már legalább 1964 óta megtelepedett Keszthelyen és ALMÁDI (2002) szavait idézve 2001-ben a „leggyakoribb pázsitfű gyom” volt az egyetemi szőlősben. A B. catharticus is legalább öt éve folyamatosan jelen van Pécsett, a Bányakapitányság udvarán. Tehát mindkét taxon rendelkezik dokumentált, állandó, önfenntartó populációval, így véleményünk szerint meghonosodottnak tekinthetők.

Érdemes megjegyezni, hogy a B. catharticus pécsi egyedei még novemberben is, az első fagyokig virágoztak. Ez jóval túlnyúlik a SOMLYAY (2009) határozókulcsában jelzett májusjúliusi virágzási időszakon. STEWART (1996) szerint egy jelentős téli aktivitással rendelkező fajról van szó, így nem meglepő az észlelt késő őszi virágzása Pécsett. 


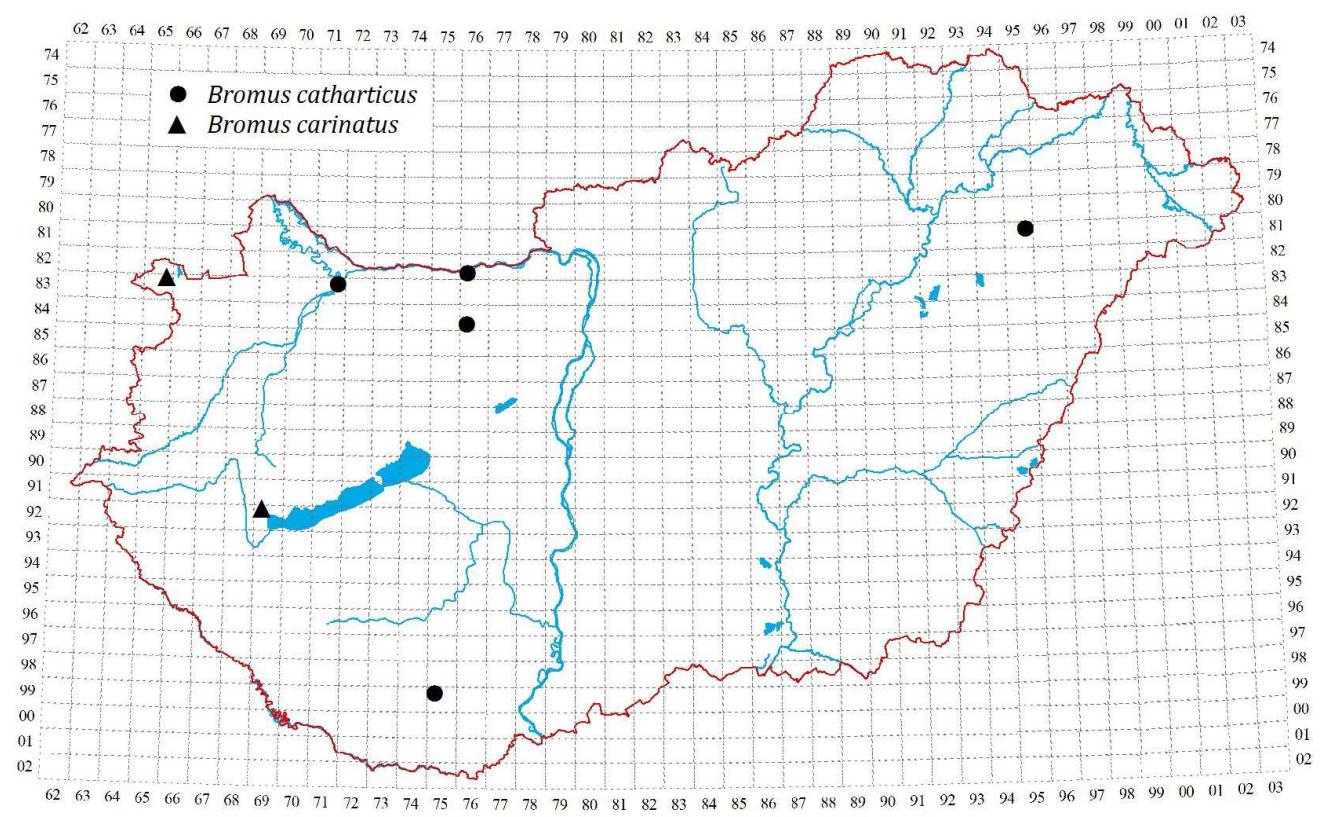

1. ábra. A Bromus carinatus és a B. catharticus eddigi előfordulási adatai Magyarországon.

Fig. 1. Records of Bromus carinatus and B. catharticus in Hungary.

\section{Köszönetnyilvánítás}

Köszönettel tartozunk Schmidt Dávidnak és Pál Róbertnek az irodalmazás során nyújtott segítségükért, továbbá Barina Zoltánnak a Növénytár anyagának rendelkezésünkre bocsátásáért, Bódis Juditnak pedig a keszthelyi herbárium áttekintéséért. Továbbá köszönjük Somlyay Lajosnak, lektorunknak a kézirathoz füzött hasznos észrevételeit.

\section{Irodalomjegyzék}

AlmÁDI L. (2002): Bromus carinatus Keszthelyen. - In: Anon. (szerk.), Aktuális flóra- és vegetációkutatás a Kárpát-medencében V. (2002. március 8-10.), Összefoglalók, Pécs, p. 11.

BALOGH L., DANCZA I. \& KIRÁLY G. (2004): A magyarországi neofitonok időszerű jegyzéke és besorolásuk inváziós szempontból. - In: MıнÁLY B \& BoTTA-DukÁT Z. (szerk.), Biológiai inváziók Magyarországon. Özönnövények. TermészetBúvár Alapítvány Kiadó, Budapest, pp. 61-92.

BARINA Z. (2007): A Vértes és környéke florisztikai kutatásának eredményei I. - Kitaibelia 12: 30-40.

KIRÁLY G. \& KiRÁLY A. (1999): Adatok és kiegészítések a magyar flóra ismeretéhez. - Kitaibelia 4: 229-246.

KIRÁLY G., BARANYAI-NAGY A., KEREKES Sz., KIRÁLY A. \& KorDA M. (2010): Kiegészítések a magyar adventívflóra ismeretéhez IV. - Flora Pannonica [2009]7: 3-31.

PoLGÁr S. (1912): Győrmegye növényföldrajza és edényes növényeinek felsorolása. - Magyar Botanikai Lapok 9: 308-338.

PolGÁR S. (1914): Újabb adatok Győr adventivus és ruderalis flórájához. - Magyar Botanikai Lapok 13: 60-69.

PolGÁR S. (1918): Újabb adatok Győr adventiv flórájához II. - Magyar Botanikai Lapok 17: 27-39.

PolGÁR S. (1941): Győrmegye flórája. - Botanikai Közlemények 38: 201-352.

ScнмiDT D. (szerk.) (2014): Győr edényes flórája. Enumeráció. - Kézirat, Győr.

SomLYAY L. (2001): A rozsnok (Bromus L.) nemzetség kutatásának története és jelenlegi állása Magyarországon. - Kitaibelia 6: 251-257. 
SomlYAY L. (2009): Bromus L. [incl. Anisantha K. Koch, Bromopsis (Dumort.) Fourr., Ceratochloa DC. et P. Beauv.] - Rozsnok. - In: KIRÁLY G. (szerk.), Új magyar füvészkönyv. Magyarország hajtásos növényei. Határozókulcsok. ANPI, Jósvafő, pp. 516-519.

Stewart, A.V. (1996) Potential value of some Bromus species of the section Ceratochloa. - New Zealand Journal of Agricultural Research 39: 611-618.

TakÁcs A., NAgY T., FeKETE R., Lovas-Kiss Á., LjubKa T., LÖKI V., LisZTEs-Szabó Zs. \& MolnáR V. A. (2014): A Debreceni Egyetem Herbáriuma (DE) I.: A „Soó Rezső Herbárium”. - Kitaibelia 19: 142-155.

Verloove, F. (2012): A revision of Bromus section Ceratochloa (Pooideae, Poaceae) in Belgium. Dumortiera 101: 30-45.

Williams, W. M., Stewart, A. V. \& Williamson, M. L. (2011): Bromus. - In: Kole, C. (ed.), Wild Crop Relatives: Genomic and Breeding Resources, Millets and Grasses. Berlin, pp. 15-30.

Beérkezett / received: 2015. 01. 08. • Elfogadva / accepted: 2015. 02. 25. 